1 OPEN ACCESS

Citation: Potvin C, Sharma D, Creed I, Aitken S, Anctil F, Bennett E, Berkes F, Bernstein S, Bleau N, Bourque A, Brown B, Burch S, Byrne J, Cunsolo A, Dale A, de Lange D, Dyck B, Entz M, Etcheverry J, Faucher R, Fenech A, Fraser L, Henriques I, Heyland A, Hoffmann M, Hoberg G, Holden M, Huang G, Jacob AL, Jodoin S, Kemper A, Lucotte M, Maranger R, Margolis L, Mauro I, McDonnell J, Meadowcroft J, Messier C, Mkandawire M, Morency C, Mousseau N, Oakes K, Otto S, Palmater P, Palmer TS, Paquin D, Perl A, Potvin A, Ramos H, Raudsepp-Hearne C, Richards N, Robinson J, Sheppard S, Simard S, Sinclair BJ, Slawinski N, Stoddart M, Villard M-A, Villeneuve $C$, and Wright T. 20 17. Stimulating a Canadian narrative for climate. FACETS 2: |3|-|49. doi: I 0.1 | 39 | facets-20 I 6-0029

Editor: C. Scott Findlay

Received: June 17, 2016

Accepted: November 6, 2016

Published: February 14, 2017

Copyright: (C) 2017 Potvin et al. This work is licensed under a Creative Commons Attribution 4.0 International License (CC BY 4.0), which permits unrestricted use, distribution, and reproduction in any medium, provided the original author(s) and source are credited.

Published by: Canadian Science Publishing

\section{Stimulating a Canadian narrative for climate}

Catherine Potvin $^{a \star}$, Divya Sharma ${ }^{a}$, Irena Creed ${ }^{b}$, Sally Aitken ${ }^{c}$, François Anctil $^{d}$, Elena Bennett ${ }^{e}$, Fikret Berkes $^{\mathrm{f}}$, Steven Bernstein ${ }^{\mathrm{g}}$, Nathalie Bleau ${ }^{\mathrm{h}}$, Alain Bourque ${ }^{\mathrm{i}}$, Bryson Brown ${ }^{\mathrm{j}}$, Sarah Burch ${ }^{\mathrm{k}}$, James Byrne', Ashlee Cunsolo $^{m}$, Ann Dale ${ }^{n}$, Deborah de Lange ${ }^{o}$, Bruno Dyck ${ }^{p}$, Martin Entz ${ }^{q}$, José Etcheverry ${ }^{\mathrm{r}}$, Rosine Fauchers, Adam Fenech ${ }^{\mathrm{t}}$, Lauchlan Fraser ${ }^{\mathrm{u}}$, Irene Henriques ${ }^{\mathrm{v}}$, Andreas Heyland $^{\mathrm{w}}$, Matthew Hoffmann ${ }^{\mathrm{x}}$, George Hoberg ${ }^{\mathrm{y}}$, Meg Holden ${ }^{\mathrm{z}}$, Gordon Huang ${ }^{\text {aa }}$, Aerin L. Jacob $^{\text {ab }}$, Sebastien Jodoin ${ }^{\text {ac }}$, Alison Kemper ${ }^{\text {ad }}$, Marc Lucotte ${ }^{\text {ae }}$, Roxane Maranger ${ }^{\text {af }}$, Liat Margolis $^{\text {ag }}$, Ian Mauro ${ }^{\text {ah }}$, Jeffrey McDonnell ${ }^{\mathrm{ai}}$, James Meadowcroft ${ }^{\text {aj }}$, Christian Messier ${ }^{\text {ak }}$, Martin Mkandawire $^{\text {al }}$, Catherine Morency ${ }^{\text {am }}$, Normand Mousseau ${ }^{\text {an }}$, Ken Oakes ${ }^{\text {ao }}$, Sarah Otto ${ }^{\text {ap }}$, Pamela Palmater ${ }^{\text {aq }}$, Taysha Sharlene Palmer ${ }^{\text {ar }}$, Dominique Paquin ${ }^{\text {as }}$, Anthony Perl ${ }^{\text {at }}$, André Potvin ${ }^{\text {au }}$, Howard Ramos $^{\text {av }}$, Ciara Raudsepp-Hearne ${ }^{\mathrm{aw}}$, Natalie Richards ${ }^{\mathrm{a}}$, John Robinson ${ }^{\mathrm{ax}}$, Stephen Sheppard ${ }^{\text {ay }}$, Suzanne Simard $^{\mathrm{az}}$, Brent J. Sinclair ${ }^{\mathrm{b}}$, Natalie Slawinski ${ }^{\mathrm{ba}}$, Mark Stoddart ${ }^{\mathrm{bb}}$, Marc-André Villard ${ }^{\mathrm{bc}}$, Claude Villeneuve ${ }^{\text {bd }}$, and Tarah Wright ${ }^{\text {be }}$

${ }^{a}$ Department of Biology, McGill University, 1205 Dr. Penfield, Montreal, QC H3A 1B1, Canada; ${ }^{b}$ Department of Biology, Western University, Biological and Geological Sciences 2078, 1151 Richmond Street, London, ON N6A 5B7, Canada; ${ }^{c}$ Faculty of Forestry, University of British Columbia, Forest Sciences Centre 3041, 2424 Main Mall, Vancouver, BC V6T 1Z4, Canada; ${ }^{\mathrm{d} D e ́ p a r t e m e n t ~ d e ~ g e ́ n i e ~ c i v i l ~}$ et de génie des eaux, Université Laval, Pavillon Adrien-Pouliot 1065, avenue de la Médecine, Quebec City, QC G1V 0A6, Canada; ${ }^{e}$ Department of Natural Resource Sciences, McGill University, Macdonald-Stewart Building, 21111 Lakeshore Road, Ste. Anne de Bellevue, Quebec, QC H9X 3V9, Canada; ${ }^{\mathrm{f}}$ Natural Resource Institute, University of Manitoba, Winnipeg, MB R3T 2N2, Canada; ${ }^{\mathrm{g} D e p a r t m e n t}$ of Political Science, University of Toronto, DV 3274, 3359 Mississauga Road, Mississauga, ON L5L 1C6, Canada; ${ }^{\mathrm{h}}$ Built Environment Program, Ouranos Consortium on Regional Climatology and Adaptation to Climate Change, Montreal, 550 Sherbrooke West, West Tower, 19th Floor, Montreal, QC H3A 1B9, Canada; impacts and Adaptation Program, Ouranos, 550 Sherbrooke West, West Tower, 19th Floor, Montreal, QC H3A 1B9, Canada; ${ }^{j}$ Department of Philosophy, University of Lethbridge, B864 (University Hall), 4401 University Drive, Lethbridge, AB T1K 3M4, Canada; ${ }^{\mathrm{k}}$ Department of Geography and Environmental Management, University of Waterloo, Room EV1-103, 200 University Avenue West, Waterloo, ON N2L 3G1, Canada; ${ }^{1}$ Department of Geography, University of Lethbridge, 401 University Drive, Lethbridge,

AB T1K 3M4, Canada; ${ }^{\mathrm{m}}$ Labrador Institute of Memorial University, Room 110, College of the North Atlantic Building, P.O. Box 490, Station B, Happy Valley-Goose Bay, NL A0P 1E0, Canada; ${ }^{\mathrm{n}}$ School of Environment and Sustainability, Royal Roads University, 2005 Sooke Road, Victoria, BC V9B 5Y2, Canada; ${ }^{\circ}$ Ted Rogers School of Management, Ryerson University, 350 Victoria Street, Toronto, ON M5B 2K3, Canada; ${ }^{\mathrm{P} A s p e r}$ School of Business, University of Manitoba, 658 Drake Centre, 181 Freedman Crescent, Winnipeg, MB R3T 5V4, Canada; ${ }^{9}$ Department of Plant Science, University of Manitoba, 222 Agriculture Building, Winnipeg, MB R3T 2N2, Canada; ${ }^{\mathrm{r}}$ Faculty of Environmental Studies,

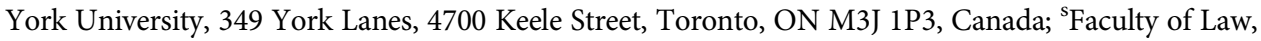
McGill University, Chancellor Day Hall, 3644 Peel Street, Montreal, QC H3A 1W9, Canada; ${ }^{\mathrm{t} C l i m a t e}$ Laboratory, University of Prince Edward Island, McDougall Hall, 320, Charlottetown, PE C1A 4P3, Canada; ${ }^{u}$ Faculty of Science, Thompson Rivers University, 900 McGill Road, Kamloops, BC V2C 0C8, Canada; 'Schulich School of Business, York University, Room N205D, 111 Ian Macdonald Boulevard, Toronto, ON M3J 1P3, Canada; ${ }^{\text {w} D e p a r t m e n t ~ o f ~ I n t e g r a t i v e ~ B i o l o g y, ~ U n i v e r s i t y ~ o f ~ G u e l p h, ~ S S C ~ 1468, ~}$ Summerlee Science Complex, Guelph, ON N1G 2W1, Canada; ${ }^{\mathrm{x}}$ Department of Political Science, University of Toronto, Sid Smith 3110, Toronto, ON M5S 3G3, Canada; ${ }^{\mathrm{y}}$ Faculty of Forestry, University of British Columbia, Forest Sciences Centre 2045, 2424 Main Mall, Vancouver, BC V6T 1Z4, Canada; ${ }^{\mathrm{z}}$ Department of Urban Studies and Department of Geography, Simon Fraser University, 2nd Floor, 515 West Hastings Street, Vancouver, BC V6B 5K3, Canada; ${ }^{\text {aa }}$ Institute for Energy, Environment and Sustainable Communities, University of Regina, Regina, SK S4S 0A2, Canada; ${ }^{\text {ab }}$ School of Environmental 
Studies, University of Victoria, P.O. Box 1700 STN CSC, Victoria, BC V8W 2Y2, Canada; ${ }^{\text {ac }}$ Faculty of Law, McGill University, New Chancellor Day Hall, 3644 Peel Street, Room 617, Montreal, QC H3A 1W9, Canada; ${ }^{\text {ad }}$ Faculty of Entrepreneurship, Ryerson University, TRS2-121, 350 Victoria Street, Toronto, ON M5B 2K3, Canada; ${ }^{a}$ Department of Earth and Atmospheric Sciences, Université du Québec à

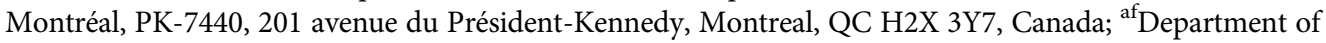
Biological Sciences, Université de Montréal, Pavillon Marie-Victorin, Ext. F234-6, 90 avenue Vincent-

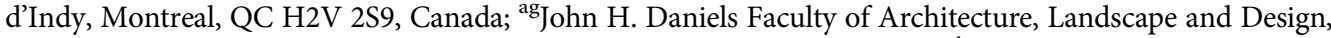
University of Toronto, 230 College Street, Toronto, ON M5T 1R2, Canada; ${ }^{\text {ah }}$ Department of Geography, University of Winnipeg, 5L33, 515 Portage Avenue, Winnipeg, MB R3B 2E9, Canada; ${ }^{\text {ai }}$ School of Environment and Sustainability, University of Saskatchewan, Kirk Hall 117 Science Place, Saskatoon,

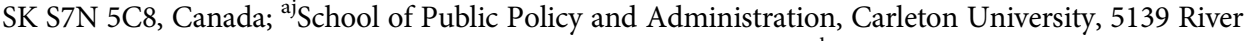
Building, 1125 Colonel By Drive, Ottawa, ON K1S 5B6, Canada; ${ }^{\mathrm{ak}}$ Department of Biological Sciences, Université de Québec en Outaouais, 283 Boul Alexandre-Taché, Gatineau, QC J8X 3X7, Canada; ${ }^{\mathrm{al}}$ Verschuren Centre for Sustainability in Energy and the Environment, Cape Breton University, CS201, 1250 Grand Lake Road, Sydney, NS B1P 6L2, Canada; ${ }^{a m}$ Department of Civil, Geological and Mining Engineering, Polytechnique Montréal, B-324.3, 2900, boul. Édouard-Montpetit, 2500, chemin de Polytechnique, Montreal, QC H3T 1J4, Canada; ${ }^{\text {an }}$ Départment de Physique, Université de Montréal, Pavillon Roger-Gaudry, Bur. A436, 2900, boul. Édouard-Montpetit, Montreal, QC H3T 1J4, Canada; ${ }^{\text {ao }}$ Department of Biology, Cape Breton University, Suite CS207, P.O. Box 5300, 1250 Grand Lake Road, Sydney, NS B1P 6L2, Canada; ${ }^{\text {ap }}$ Department of Zoology, University of British Columbia, 6270 University Boulevard, Vancouver, BC V6T 1Z4, Canada; ${ }^{\mathrm{aq}}$ Department of Politics and Public Administration, Ryerson University, 350 Victoria Street JOR700, Toronto, ON M5B 2K3, Canada; ${ }^{\text {ar Environmental }}$ Sustainability Research Centre, Brock University, 1812 Sir Isaac Brock Way, St. Catharines, ON L2S 3A1, Canada; ${ }^{\text {as }}$ Climate Simulation and Analysis, Ouranos Consortium on Regional Climatology and Adaptation to Climate Change, Montreal, 550 Sherbrooke West, West Tower, 19th Floor, Montreal, QC H3A 1B9, Canada; ${ }^{\text {at }}$ Department of Political Science, Simon Fraser University, HC 2124, 8888

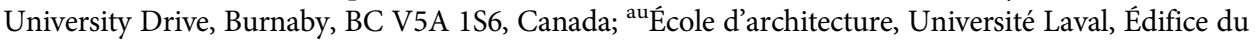

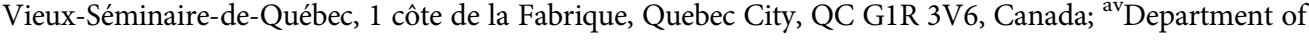
Sociology and Social Anthropology, Dalhousie University, Room 1117, McCain Building, 6135 University Avenue, P.O. Box 15000, Halifax, NS B3H 4R2, Canada; ${ }^{a w}$ Quebec Centre for Biodiversity Science, McGill University, Stewart Biology Building Office W6/19, 1205 Dr. Penfield Avenue, Montreal, QC H3A 1B1, Canada; ${ }^{\text {ax }}$ Munk School of Global Affairs, University of Toronto, 1 Devonshire Place, Toronto, ON M5S 3K7, Canada; ${ }^{\text {ay } C o l l a b o r a t i v e ~ f o r ~ A d v a n c e d ~ L a n d s c a p e ~ P l a n n i n g ~(C A L P), ~ F a c u l t y ~ o f ~ F o r e s t r y, ~}$ University of British Columbia, Forest Sciences Centre 3601, 2424 Main Mall, Vancouver, BC V6T 1Z4, Canada; ${ }^{a}$ Faculty of Forestry, University of British Columbia, Forest Sciences Centre 3601, 2424 Main

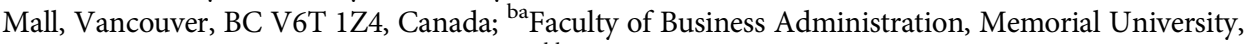

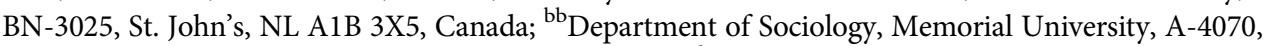

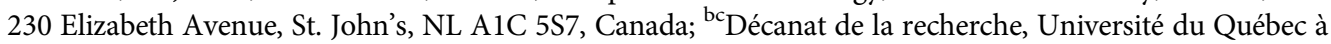

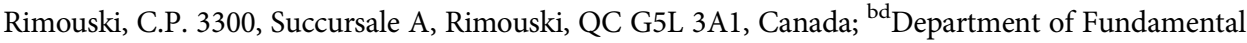
Sciences, Université du Québec à Chicoutimi, 555, boulevard de l'Université, Chicoutimi, QC G7H 2B1,

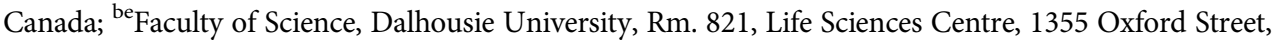
Halifax, NS B3H 4R2, Canada

*catherine.potvin@mcgill.ca

\section{Abstract}

This perspective documents current thinking around climate actions in Canada by synthesizing scholarly proposals made by Sustainable Canada Dialogues (SCD), an informal network of scholars from all 10 provinces, and by reviewing responses from civil society representatives to the scholars' proposals. Motivated by Canada's recent history of repeatedly missing its emissions reduction targets and failing to produce a coherent plan to address climate change, SCD mobilized more than 60 scholars to identify possible pathways towards a low-carbon economy and sustainable society 
and invited civil society to comment on the proposed solutions. This perspective illustrates a range of Canadian ideas coming from many sectors of society and a wealth of existing inspiring initiatives. Solutions discussed include climate change governance, low-carbon transition, energy production, and consumption. This process of knowledge synthesis/creation is novel and important because it provides a working model for making connections across academic fields as well as between academia and civil society. The process produces a holistic set of insights and recommendations for climate change actions and a unique model of engagement. The different voices reported here enrich the scope of possible solutions, showing that Canada is brimming with ideas, possibilities, and the will to act.

Key words: climate change, governance, low-carbon transition, energy production, energy consumption

\section{Stimulating a Canadian narrative for climate action}

Past climate change discourses have been characterized either as alarmist (emphasizing the devastation to come), dismissive (rejecting the alarmist discourse), or based on small actions (every small step counts) (Ereaut and Segnit 2006). None of these have led to worldwide climate action at the scale or pace necessary to prevent dangerous anthropogenic climate change (New et al. 2011). Several authors have therefore argued for a new climate change narrative that fosters accelerated action (Moser and Dilling 2007; Risbey 2008).

For Canada, the 2015 October federal election and the December United Nations Framework Convention on Climate Change COP21 meetings offered key opportunities to shift climate discourse. Motivated by Canada's recent history of repeatedly missing its emissions reduction targets and failing to produce a comprehensive climate action plan, Sustainable Canada Dialogues (SCD) (http://sustainablecanadadialogues.ca/en/scd) mobilized more than 60 scholars from all provinces in 2014-2015 to reach a consensus on possible pathways towards a low-carbon economy and sustainable society. This effort resulted in a position paper, "Acting on Climate Change: Solutions from Canadian Scholars", proposing 10 policy orientations that could be implemented now to begin the transition to low-carbon development pathways (Potvin et al. 2015). Bushell et al. (2015) proposed that new climate narratives must be constructed as an iterative process that fully engages relevant stakeholders. The SCD scholars (hereafter scholars), therefore, broadly invited representatives from diverse civil society perspectives to respond to these proposals. Twenty-eight contributions were received, some invited, and others offered, from an Indigenous institution, non-governmental organizations, businesses, labour groups, and private citizens (Fig. 1). These were compiled in "Acting on Climate Change: Extending the Dialogue Among Canadians" (Sharma and Potvin 2015).

This perspective synthesizes scholars' policy orientations and reviews input from the civil society dialogues, documenting the breadth of current thinking around climate actions in Canada. This process of knowledge synthesis/creation is novel and important because it provides a working model for making connections across academic fields as well as between academia and civil society. The process produces a holistic set of insights and recommendations for climate change actions and a unique model of engagement.

\section{Reaching a scholarly consensus}

To reach a consensus on desirable climate actions, scholars used a Delphi survey (see Methods in Supplementary Material) to answer the question "Bearing in mind the upcoming federal elections and the United Nations Climate Change Conference, Paris 2015, what key recommendations or solutions do you think Sustainable Canada Dialogues could propose to Canadian policymakers to 


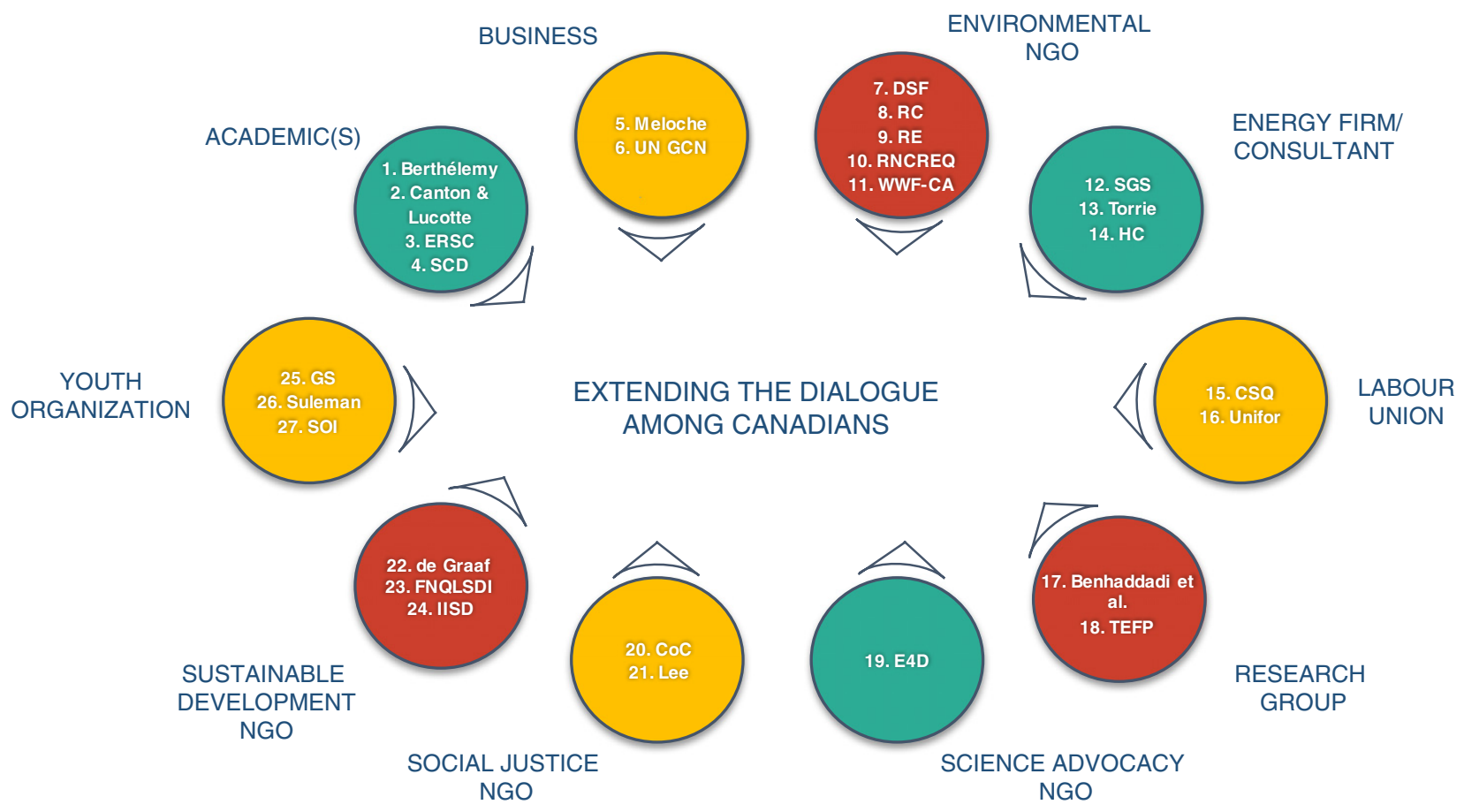

Fig. 1. Contributors to Acting on Climate Change: Extending the Dialogue Among Canadians, arranged according to sector of society. 1. Nathalie Berthélemy, 2. Mathieu Canton and Marc Lucotte, Université du Québec à Montréal, 3. Liette Vasseur and Gary Pickering, Environmental Sustainability Research Centre, Brock University, 4. Natalie Richards, Mark Stoddart, Ashlee Cunsolo Willox, Catherine Potvin and the Sustainable Canada Dialogues' Visioning Team, 5. François Meloche, Bâtirente, 6. United Nations Global Compact Network Environment Committee, 7. Ian Bruce and Ryan Kadowaki, David Suzuki Foundation, 8. Michael Small and Claire Havens, Renewable Cities, 9. Caroline Sanchez Valero, Réseau Environnement, 10. Philippe Bourke and Cédric Chaperon, Regroupement national des conseils régionaux de l'environnement du Québec, 11. David Miller, Susan Evans and Farid Sharifi, WWF-Canada, 12. Adam Day and Sean Fleming, Solar Global Solutions, 13. Ralph Torrie, Torrie Smith Associates, 14. Philip Raphals and Rick Hendriks, Helios Centre, 15. Erik Bouchard-Boulianne and Jean Robitaille, la Centrale des syndicats du Québec, 16. Lana Payne and Jim Stanford, Unifor, 17. Mohammed Benhaddadi, Pierre Blanchet, Jean-François Boucher, Jean-François Desgroseilliers, Érick Lachapelle, Isabelle Lessard, Annie Levasseur, Paul Lewis, Valérie Patreau, André Potvin, Johanne Saint-Charles, Juan Torres and Cathy Vaillancourt, Centre interdisciplinaire de recherche en opérationnalisation du développement durable, 18. Alex Boston, Trottier Energy Futures Project, 19. W.R. Peltier, John Stone, Tim Takaro and Alana Westwood, Evidence for Democracy, 20. Andrea Donahue-Harden, Council of Canadians, 21. Marc Lee, Canadian Centre for Policy Alternatives, 22. Megan de Graaf, Fundy Biosphere Reserve, 23. Catherine Béland and Michael Ross, First Nations of Quebec and Labrador Sustainable Development Institute, 24. Scott Vaughan, International Institute for Sustainable Development, 25. Paul Kershaw, Generation Squeeze, 26. Shazeen Suleman, Canadian Commission for UNESCO Youth Advisory Group, and 27. Corinne Cadoret and Noah Picard-Simon, NordMAB’s Students On Ice. See http://sustainablecanadadialogues.ca/en/scd/extendingthedialogue.

foster sustainable development in Canada?”. The first survey round resulted in 299 statements, many of which were "operational solutions" such as "Compel manufacturers to include their vehicle's greenhouse gas emissions in advertisements"; "Each new urban development project should contribute towards the creation of walkable pedestrian-oriented communities"; "Build an electric train in the Quebec-Windsor corridor"; and "All government purchases should be smart and fair trade". Together, these initial statements represent a wealth of ideas that could serve to stimulate actions (Table S1).

The Delphi survey continued for two additional rounds. In round 2, scholars were asked to rate the initial 299 statements according to their perceived importance. The 51 statements receiving a high median score and low interquartile range in round 2 served as input for round 3 in which actions were ranked for achievability and potential impact. The most highly ranked statements focused principally 
on energy (seven statements), urban design, and transportation (six statements) (Table S1). It is noteworthy that five of the seven statements pertaining to energy addressed fossil fuel production; for example, "Federal and provincial governments should avoid costly and irrevocable investments in obsolete energy sources (e.g., fossil fuel-based) and technologies in the short term". Transportation was similarly dominant in the selected statements, being the focus of five out of six, including "Integrate sustainable development and climate change into the heart of territorial and urban planning (laws, orientation, etc.), including incentives to reduce reliance on cars, supporting greater expansion of public transportation, tolls in areas with heavier traffic, improving current road infrastructure without creating new roads, etc." (Table 1).

\section{Climate change governance}

\section{Scholars' proposal}

Canada's failure to meet its emissions reduction targets has been attributed in part to the absence of a cohesive vision across governmental levels (Jones 2014), highlighting again the importance of governance. Long-term low-carbon transition entails application of policies that are most appropriate according to their place and the current state of regional knowledge, then systematically monitoring progress and adjusting efforts over time based on lessons learned (Meadowcroft 2011). Scholars therefore envisioned climate governance as a multi-level process of cooperation and collaboration between citizens and different government levels: municipal, territorial, provincial, federal, and Indigenous.

Many different routes and pathways can be consistent with a low-carbon future in Canada. Decarbonisation priorities in Quebec (with its hydro-based electricity system) will be different from those in Alberta (which relies extensively on coal for electricity and whose hydrocarbon extraction sector constitutes a large component of the provincial economy). Different regions will therefore opt for distinct combinations of these and other technologies depending on their visions, energy portfolio (CESAR 2016), and emissions sectors (Layzell 2014).

\section{Civil society responses}

Calls for novel multi-level climate governance were at the heart of 18 out of 28 contributions received. Civil society responses emphasized the need for clear federal leadership (Bruce and Kadowaki 2015; Peltier et al. 2015; Sanchez Valero 2015; GCNCEC 2015). Vaughan (2015) proposed a clear and predictable federal regulatory framework would create opportunities for transition which, according to Canada's Global Compact environment committee (GCNCEC 2015), could stimulate businesses to integrate climate change considerations into their strategies. According to Bruce and Kadowaki (2015), Canada would be on course to meet its emissions reduction target of $17 \%$ by 2020 had it adopted, in 2008, the best existing provincial emissions reduction policies in a national framework. Several civil society responses emphasized the crucial role of cities and local government leadership in transitioning to low-carbon (Boston 2015; Bourke and Chaperon 2015; Sanchez Valero 2015; Small and Havens 2015) because they concentrate wealth, innovation, education, consumption, and emissions, as well as poverty and vulnerability.

Civil society contributors also felt climate change governance should be participatory (Benhaddadi et al. 2015; Richards et al. 2015) and evidence-based (Kershaw 2015; Peltier et al. 2015), allowing all Canadians to act on the future at hand by engaging in a transition (de Graaf 2015; Robitaille 2015; Vasseur and Pickering 2015). Some contributors called for inclusion of youth (Cadoret and PicardSimon 2015; Kershaw 2015; Robitaille 2015; Suleman 2015) and local knowledge (Benhaddadi et al. 2015; de Graaf 2015; Richards et al. 2015; Robitaille 2015; Vasseur and Pickering 2015) in the climate narrative, while acknowledging the jurisdictional status of Indigenous peoples (Béland and Ross 2015). 
Table 1. Statements retained in round 3 of the Delphi survey that asked SCD scholars "Bearing in mind the upcoming federal elections and the United Nations Climate Change Conference, Paris 2015, what key recommendations or solutions do you think Sustainable Canada Dialogues could propose to Canadian policymakers to foster sustainable development in Canada?".
Topic Statement

Energy

1. Federal and provincial governments should develop a national energy policy and long-term plans, respectively, for transitioning to a mainly renewable energy economy.

Note: One scholar stresses that this statement needs to be fine-tuned. Renewable energy is not the answer to everything and not all renewable energy is sustainable.

2. Terminate direct and indirect domestic subsidization of the petroleum industry. Redirect these funds to initiatives aiming to reduce GHG emissions.

3. Support international efforts to end fossil fuel subsidies globally.

4. Implement a moratorium on further development of the oil sands.

5. Immediately embark on a trajectory of ending oil sand extraction in Alberta within 10 years:

i. Continuing to do so will put the world on the most aggressive $\mathrm{CO}_{2}$ growth curve, spelling disaster;

ii. Continuing to do so endangers downstream ecosystems in Alberta.

6. Federal and provincial governments should avoid costly and irrevocable investments in obsolete energy sources, e.g., fossil fuel-based technologies, in the short term.

7. Novel energy policies should promote renewable energy, low energy consumption, residential insulation, and the use of environmentally sound designs. Environmental performance considerations should be integrated into federal decision-making processes. Aggressive policies need not be expensive (e.g., adding solar hot water to every new house would be $\sim 1 \%$ of the house's value.

Low-carbon policy

1. Develop a national climate change policy.

2. Put a price on carbon either by joining the international carbon market or through a carbon tax for all enterprises operating in Canada.

Cities/transportation

1. Set national automobile emission standards that match regions with "best practices" (i.e., California within North America).

2. Introduce more rapid transit within cities. Rapid transit need not be expensive (e.g., no need for subways), but can be facilitated by clever use of buses (see example of Jaime Lerner in Curitiba, Brazil (Adler 2016)).

3. Support sustainable transportation initiatives at the municipal level, including through federal infrastructure money.

4. Integrate sustainable development and climate change into the heart of territorial and urban planning (laws, orientation, etc.), including incentives to move away from reliance on cars, support for greater expansion of public transportation, tolls in areas with heavier traffic, improvements to current road infrastructure without creating new roads, etc.

5. Create "smart cities", which means that all of the systems (water, waste, energy, transportation, buildings, etc.) are made sustainable, clean, accessible, and integrated and connected using clean advanced technologies. In doing so, enforce sustainable sourcing for new building and retrofits.

6. Develop new building codes that improve housing sector energy efficiency. (Homeowners often weigh the upfront price of a house more heavily than operating costs; this makes it important to use the building code rather than rely on builders and homebuyers to make the best decision independently.)

Land use

1. Decrease deforestation practices and increase protection of forests-natural carbon sinks. 
Potvin et al.

Table 1. (concluded)

Topic

Statement

Information, education,

and research

1. Inform society on climate change mitigation and adaptation so that everyone can understand the key issues and act on them. Inform the necessary stakeholders and decision makers of the risks and available options linked to climate change and promote dialogue regarding possible measures of mitigation and adaptation.

2. Promote applied research in the domain of sustainable cities, taking into account mitigation of and adaptation to climate change impacts.

Note: Statements with high feasibility and potential impact (i.e., with median score of 3 and a low dispersion (interquartile range of 0 ( $N=2$ ) or $1(N=16)$ ) were retained. A total of 43 scholars answered at least one of the three rounds. For further details, see Supplementary Methods.

Furthermore, Vasseur and Pickering (2015) proposed a shift in decision-making and mindset to embrace both adaptive and anticipatory governance as a stepping stone to a more resilient country in the face of climate change, because benefits for public health (Peltier et al. 2015; Suleman 2015), biodiversity (Boston 2015; Miller et al. 2015; GCNCEC 2015), water (de Graaf 2015; Donahue-Harden 2015; GCNCEC 2015), and social equity (Béland and Ross 2015; Donahue-Harden 2015) could emerge from a well-designed low-carbon transition.

\section{Implementation}

Scholars indicated that effective climate change governance should (i) favour policy coherence and alignment within governments; (ii) support policy congruence between levels of government; and (iii) enhance participatory policy development to close implementation gaps. Canada has past experience in governance innovations that can be drawn upon to facilitate climate governance. Examples include the Canadian Council of Environment Ministers and the national, provincial, and municipal round tables on environment and economy, and their structural arrangements (Dale 2005).

According to Bourke and Chaperon (2015), fully engaging with municipalities would enable identification of locally appropriate promising climate actions. Sanchez Valero (2015) proposed as initial steps that every municipality have a greenhouse gas inventory and an action plan to reduce emissions and support increased public awareness, as illustrated by the Federation of Canadian Municipalities in Partners for Climate Protection (Table 2), a guide for municipalities towards climate action. Indeed, creation of such municipal inventories in British Columbia triggered by the 2008 Climate Action Plan (Province of British Columbia 2008) was part of a much wider suite of climate change actions that followed (Burch et al. 2014). In Quebec, the initiative Par notre propre énergie provided a platform to showcase innovative projects that reduce fossil fuel consumption, thus favouring knowledge sharing and stimulating the low-carbon transition (Table 2).

Climate change awareness will play a key role in implementing efficient climate change governance (Bourke and Chaperon 2015; Sanchez Valero 2015; GCNCEC 2015). Experiences of the Fundy Biosphere Reserve (de Graaf 2015), Brundtland schools (Robitaille 2015), Youth Advisory Group for the Canadian Commission for UNESCO (Suleman 2015), and Students On Ice (Cadoret and Picard-Simon 2015) are examples of tangible initiatives that raise awareness and engage youth in the pursuit of a sustainable society (Table 2). 
Potvin et al.

Table 2. Existing Canadian initiatives cited in both Acting on Climate Change: Solutions from Scholars and Extending the Dialogue Among Canadians reports that reflect proposals of SCD and civil society and provide guidance on how the low-carbon transition can be operationalized.

$\begin{array}{lll}\text { Contribution } \quad \text { Name of initiative Description } & \text { Link }\end{array}$

Energy

production

\begin{tabular}{|c|c|c|}
\hline Montreal Carbon Pledge & $\begin{array}{l}\text { Measures carbon footprint of investment } \\
\text { portfolios }\end{array}$ & http://montrealpledge.org \\
\hline Suncor & $\begin{array}{l}\text { Invests in technology to reduce } \\
\text { environmental impact }\end{array}$ & http://www.suncor.com/default.aspx \\
\hline Par notre propre énergie & $\begin{array}{l}\text { Creates conditions to reduce oil } \\
\text { dependence in Quebec }\end{array}$ & http://www.par-notre-propre-energie.com \\
\hline $\begin{array}{l}\text { High Conservation Value } \\
\text { framework of Forest } \\
\text { Stewardship Council }\end{array}$ & $\begin{array}{l}\text { Identifies places of high ecological value } \\
\text { to avoid in renewable projects }\end{array}$ & $\begin{array}{l}\text { https://ic.fsc.org/en/smallholders/support/technical- } \\
\text { materials/high-conservation-values-and-biodiversity }\end{array}$ \\
\hline $\begin{array}{l}\text { Investment in wind energy in } \\
\text { Paintearth County and } \\
\text { Pincher Creek, Alberta }\end{array}$ & $\begin{array}{l}\text { Establishment of wind farms in districts } \\
\text { of Alberta }\end{array}$ & $\begin{array}{l}\text { http://canwea.ca/wp-content/uploads/2014/01/ } \\
\text { canwea-AB-brochure-e-web-v1.pdf }\end{array}$ \\
\hline Ontario feed-in tariff program & $\begin{array}{l}\text { Payments for renewable energy use to } \\
\text { encourage investment }\end{array}$ & http://fit.powerauthority.on.ca \\
\hline Divest McGill & $\begin{array}{l}\text { Campaigns for McGill University to } \\
\text { divest its endowment from the fossil } \\
\text { fuel industry }\end{array}$ & http://divestmcgill.com \\
\hline Columbia Hydro Constructors & $\begin{array}{l}\text { Implemented employment equity } \\
\text { programs in the late 1990s that } \\
\text { provided training and opportunities } \\
\text { for marginalized groups in the province }\end{array}$ & http://columbiapower.org/about/ \\
\hline $\begin{array}{l}\text { Sustainable Development } \\
\text { Technology Canada }\end{array}$ & $\begin{array}{l}\text { Provides venture capital to support } \\
\text { precommercialization development } \\
\text { of clean technology options }\end{array}$ & https://www.sdtc.ca/en \\
\hline $\begin{array}{l}\text { Climate Change and Emissions } \\
\text { Management initiative }\end{array}$ & $\begin{array}{l}\text { Provides start-up capital to promising } \\
\text { clean technologies }\end{array}$ & http://ccemc.ca/about/ \\
\hline $\begin{array}{l}\text { Flow-through shares for clean } \\
\text { energy modeled after mining } \\
\text { industry }\end{array}$ & - & http://miningtaxcanada.com/flow-through-shares/ \\
\hline
\end{tabular}

Energy

consumption

$\begin{array}{llc}\begin{array}{l}\text { Neighbourhood Energy Utility, } \\ \text { Vancouver }\end{array} & \begin{array}{c}\text { Recapture of waste water to improve } \\ \text { building energy efficiency }\end{array} & \begin{array}{c}\text { http://vancouver.ca/docs/planning/renewable-energy- } \\ \text { neighbourhood-utility-factsheet.pdf }\end{array} \\ \text { Montreal Transit } & \text { Commitment to 100\% electrified transit } & \begin{array}{c}\text { http://www.stm.info/en/about/major_projects/ } \\ \text { electrification-surface-system }\end{array}\end{array}$

ecoENERGY and ENERGY
STAR

Pay-as-you-save, Manitoba
Programs that improve consumer product efficiency, taking pressure off the grid and helping reduce utility peak energy requirements

Manitoba Hydro pays upfront energy upgrade costs and households pay from savings in utility bills http://www.nrcan.gc.ca/energy/funding/current-fundingprograms/eii/4985 and http://www.nrcan.gc.ca/energy/ products/energystar/12519

https://www.hydro.mb.ca/NewsReleases/GetDetail?
hdnAct=E\&hdnTXT='PAYS\%20Financing\%
20Program\%20makes\%20energy\%20efficiency\% 20more\%20accessible'

(continued) 
Potvin et al.

Table 2. (concluded)

\section{Contribution}

Name of initiative

Description

Link

Adaptive

governance

\begin{tabular}{|c|c|c|c|}
\hline & $\begin{array}{l}\text { Établissement vert Brundtland } \\
\quad \text { (EVB-CSQ) }\end{array}$ & $\begin{array}{l}\text { Network of institutions to educate public } \\
\text { and youth for sustainable development }\end{array}$ & http://evb.lacsq.org \\
\hline & Fundy Biosphere Reserve & $\begin{array}{l}\text { Enhances communities' and students' } \\
\text { climate change adaptation capacity } \\
\text { and awareness }\end{array}$ & http://www.fundy-biosphere.ca/en/ \\
\hline & $\begin{array}{l}\text { Canadian Commission for } \\
\text { UNESCO Youth Advisory } \\
\text { Group }\end{array}$ & $\begin{array}{l}\text { Network of youth to identify youth's } \\
\text { concerns, recommendations, and } \\
\text { coordinate projects }\end{array}$ & http://unesco.ca/home-accueil/youth-jeunesse $\% 20$ new \\
\hline & NordMAB's Students On Ice & $\begin{array}{l}\text { Educational youth expeditions to polar } \\
\text { regions }\end{array}$ & http://studentsonice.com \\
\hline & Climat municipalités, Quebec & $\begin{array}{l}\text { Helps municipalities contribute to } \\
\text { climate change mitigation }\end{array}$ & $\begin{array}{l}\text { http://www.mddelcc.gouv.qc.ca/programmes/ } \\
\text { climat-municipalites/ }\end{array}$ \\
\hline & Partners for Climate Protection & $\begin{array}{l}\text { Promotes GHG reduction initiatives in } \\
\text { municipalities }\end{array}$ & $\begin{array}{l}\text { http://www.fcm.ca/home/programs/ } \\
\text { partners-for-climate-protection.htm }\end{array}$ \\
\hline
\end{tabular}

\section{Pricing carbon to begin the transition}

\section{Scholars' proposal}

Transitioning to a low-carbon economy can be facilitated by climate policies that are (i) environmentally effective, (ii) cost-effective, (iii) administratively feasible, (iv) politically feasible, and (v) equitable. Climate policy analysts widely agree that carbon pricing should be a key component of any comprehensive climate change policy, whether as a carbon tax or cap-and-trade system (Gupta et al. 2014). Carbon pricing is therefore the key enabling policy orientation.

\section{Civil society responses}

Several contributors contended the allocated value per tonne of carbon will determine the effect of a carbon price. A low price would have little impact on emissions reduction (Benhaddadi et al. 2015; Torrie 2015; Vaughan 2015), whereas a sufficiently high price could encourage fossil fuel/energy companies to internalize environmental production costs when determining future project viability (Meloche 2015). Vaughan (2015), however, recalled the importance of emissions reductions gained by measures such as efficiency standards, arguing that carbon pricing cannot replace all climate policies, but rather should be one instrument in a climate action toolbox. For GCNCEC (2015), the creation of a more predictable economic or regulatory environment is an advantage of carbon pricing. It envisions that governmental and business sectors working jointly to facilitate the implementation of a carbon pricing strategy could stem from a carbon market working hand-in-hand with renewable energy subsidies and removal of regulatory barriers.

\section{Implementation}

Scholars and civil society contributors both recognized that provinces have already invested in different mechanisms to price carbon, and that it will be crucial to coordinate actions among provinces (Benhaddadi et al. 2015; Bruce and Kadowaki 2015). Scholars proposed that any national system would require adaptation by provinces with different existing policy instruments. For example, if a national carbon tax was adopted and Quebec retained its cap-and-trade system, it could either 
negotiate an equivalency agreement that ensures its carbon price levels are similar to the rest of Canada or comply with a province-specific emission cap.

\section{Concerns}

Pricing carbon raises equity concerns (Benhaddadi et al. 2015; Bouchard-Boulianne 2015; Kershaw 2015; Lee 2015). Because implementation would inevitably raise gasoline and heating oil prices, poor and marginalized households would require support to ensure they do not bear a disproportionate cost of the low-carbon transition (Bouchard-Boulianne 2015). Many Indigenous peoples, for example, live in small, remote, and isolated communities that are off-grid and lack access to public transportation, increasing the proportion of vulnerable households (Béland and Ross 2015). Equity measures associated with carbon pricing such as tax credits or other forms of financial support to lower-income families could increase social acceptability (Benhaddadi et al. 2015; Kershaw 2015), allowing for a higher carbon price that enhances environmental effectiveness while assisting lower-income groups during the transition (Bouchard-Boulianne 2015). Although British Columbia's revenue-neutral carbon tax is often proposed as a model, Lee (2015) suggested using revenue from a carbon tax or market to support climate mitigation and adaptation initiatives that also address social equity.

\section{Energy production}

\section{Scholars' proposal}

Several policy proposals were geared towards energy production and included favouring low-carbon electricity production, fully integrating the oil and gas sectors in climate policies, and developing a national energy strategy that considers the need for energy efficiency. Wind energy alone could provide several times the existing fossil fuel and nuclear electricity at a competitive cost (Harvey 2013). It could be supplemented by solar photovoltaic, geothermal, ground-based heat recovery, biomass, and biogas to supply a considerable portion of Canada's energy needs (Barrington-Leigh and Ouliaris 2014). Furthermore, diversifying Canada's energy portfolio could improve both energy and economic security (Bridge and Le Billon 2013).

\section{Civil society responses}

Many contributions stressed the benefits of clean energy for the Canadian economy and for employment (Bouchard-Boulianne 2015; Bruce and Kadowaki 2015; Day and Fleming 2015; Lee 2015; Miller et al. 2015; Payne and Stanford 2015; Small and Havens 2015; GCNCEC 2015). Small and Havens (2015), however, emphasized the importance of energy efficiency, noting that in North America up to $40 \%$ improvement in energy efficiency will be necessary to complete the low-carbon transition they envision. Torrie (2015) observed that all published low-carbon future scenarios require much greater efficiency in electricity and fuel.

Payne and Stanford (2015, p. 71) noted that "Canada's traditional reliance on natural resource industries... complicate[s] the politics and the economics" of low-carbon transitions. Raphals and Hendriks (2015) suggested that natural gas could be used sensibly during the transition. In contrast, Lee (2015) argued that retaining fossil fuel reserves in the ground is necessary to reduce emissions by $80 \%$ by 2050 . Some expressed unease because expanding oil sands extraction could increase Canada's emissions by an approximated $100 \mathrm{Mt}$ per year, preventing the country from meeting even a low-ambition emissions reduction target (Berthélemy 2015; Donahue-Harden 2015). Because oil extraction and export are interconnected, Donahue-Harden (2015) demands that pipeline expansion be stopped. GCNCEC (2015), however, points to emerging best practices in the Canadian oil industry: for example, Suncor manages risk and takes advantage of opportunity through technological innovations such as reducing tailings, which are byproducts of the bitumen extraction process. 


\section{Implementation}

Scholars proposed capitalizing on current hydroelectric production and plentiful untapped renewable energy resources by creating east-west intelligent grid connections between provinces. Torrie (2015, p. 61) emphasized the need to consider how the "new electric grid" could accelerate renewable energy deployment by "including an array of information technologies, energy storage techniques, responsive demand technologies, and a transmission and distribution infrastructure". Because a new electrical grid would modulate the shift to renewable energy, Vaughan (2015, p. 38) called for links between "structurally rigid and capital-intensive systems (such as hydro) and more networked and modular energy innovations such as electric vehicles and wind", whereas Day and Fleming (2015) raised the potential for microgrid technologies to take full advantage of solar photovoltaics.

Civil society contributions cited a number of existing renewable energy programs and initiatives such as investment in wind energy in Paintearth County and Pincher Creek, Alberta (Table 2).

In an energy-constrained world, regulatory frameworks must stimulate effective energy management (GCNCEC 2015). Potential gains in emissions reduction and fossil fuel displacement could be achieved with efficiency standards and a national energy policy (Benhaddadi et al. 2015; Boston 2015; Bruce and Kadowaki 2015; Donahue-Harden 2015; Torrie 2015). Recognizing that energy decisionmaking is currently fragmented (with production, transport, consumption, and relevant jurisdictions largely considered in isolation), the adoption of a life-cycle approach to energy and development projects would enable accounting for both upstream and downstream impacts (Benhaddadi et al. 2015; Donahue-Harden 2015).

Finally, several contributions indicated that ceasing fossil fuel subsidies and divesting from highcarbon industries would be vital for stimulating the low-carbon transition (Donahue-Harden 2015; Kershaw 2015; Lee 2015; Meloche 2015; Richards et al. 2015; Small and Havens 2015; Vaughan 2015). Meloche (2015) described fossil fuels as risky investments for two reasons: (i) it is predicted that fuel demand will decrease with expanding electric car markets and (ii) investors will have to deal with future environmental disruption stemming from their own investments. He proposed the Montreal Carbon Pledge (Table 2), an international commitment to measure the carbon footprints of investment portfolios, as a possible first step.

\section{Concerns}

Civil society contributors suggested specific policy modifications. For example, removal of barriers to connecting renewable energy to grids (Donahue-Harden 2015) and Ontario's feed-in tariffs as a model (Day and Fleming 2015; Small and Havens 2015) (Table 2). Others contended new low-carbon electricity utilities should be either publicly- or community-owned, so as not to disenfranchise the least well off (Donahue-Harden 2015; Lee 2015).

Contributions from civil society revealed broad social justice concerns. Several contributors emphasized that energy efficiency programs should ensure social and economic benefits in meeting energy needs such as creating jobs and reducing social inequity (Donahue-Harden 2015; Kershaw 2015; Payne and Stanford 2015) to ensure that poor households and marginalized communities have access to energy-efficient appliances and heating/cooling systems (Donahue-Harden 2015). Columbia Hydro Construction, which implemented employment equity programs in the late 1990s and provided training and opportunities for marginalized groups, is an example that could be emulated (Table 2).

Recognizing that natural resource extraction and transportation, including renewable energy projects, often take place on Indigenous territories, deployment of the "new grid" must acknowledge First Nations, Inuit, and Métis as full partners (Béland and Ross 2015; Donahue-Harden 2015). This would 
entail not only culturally relevant consultations and free, prior, and informed consent (DonahueHarden 2015), but also renewable energy project ownership, full partnership or leadership, and fair sharing of benefits derived from electric network restructuration including access to low-carbon electricity (Béland and Ross 2015).

Contributors also expressed concern over potential adverse effects of hydropower expansion (Bourke and Chaperon 2015; Raphals and Hendriks 2015). Hydroelectric dams impact ecosystems and affect local populations by reducing territorial access and potentially altering eating habits and food security due to mercury contamination in the first decades of operation (Canton and Lucotte 2015). Maximizing reservoirs' use-for example, using them to harvest wind as well as hydro energy —could alleviate some concerns (Canton and Lucotte 2015). In addition, negative effects of new hydroelectric dams could be reduced by following existing best practices such as avoiding area-intensive developments in high or sensitive biodiversity zones (Miller et al. 2015). Béland and Ross (2015, p. 15) remarked that "construction of... new infrastructures will inevitably take place on Aboriginal land. The consultation, collaboration, and prior consent of the affected First Nation communities should therefore be prerequisites to the implementation of an energy policy...".

Finally, a frequent argument for continued support of the fossil fuel sector is the widespread notion of "no oil, no jobs" (Payne and Stanford 2015; Robitaille 2015). The low-carbon shift would profoundly impact job markets. Workers in shrinking sectors would need to be offered training and re-qualification for new jobs (Bouchard-Boulianne 2015; Donahue-Harden 2015; Lee 2015). These risks led some contributors to call for divestment from fossil fuels and investment in renewable energies (Donahue-Harden 2015; Meloche 2015; Small and Havens 2015). Expanding sectors such as home renovation, energy efficiency, and public transport infrastructure could then benefit from job creation (Bouchard-Boulianne 2015; Lee 2015; Payne and Stanford 2015; Robitaille 2015).

\section{Energy consumption}

\section{Scholars' proposal}

Realistic visions for a sustainable Canada require new ways of contemplating mobility (Richard and Perl 2010), shifting public attitudes and behaviours, and forward-thinking decision-making that provides access to alternative mobility modes. In Canada, energy consumption centres around two primary areas: (i) transportation (24\% of emissions) and (ii) buildings (11\% of emissions) (Environment Canada 2013). Despite a 29\% countrywide improvement in building energy efficiency between 1990 and 2007, overall energy use jumped $7 \%$ due to an increase in number of households and average home size (Office of Energy Efficiency 2010). Cities, home to 81\% of Canadians, concentrate emissions and could become foci of mitigation actions. Local governments have control over critical sources of emissions such as those related to transport (Betsill 2001; Bulkeley and Betsill 2005). Furthermore, climate change impacts are often felt at the scale of cities (Wilbanks and Sathaye 2007).

Many factors combine to affect choice of transportation mode, including household structure, age, gender, time and cost of trips on various networks, parking availability and cost at destination, presence of children in the household and their travel needs, level of car ownership, and weather conditions. When rethinking Canada's transportation system, development of new transportation technology and changing behaviour as it relates to mobility are important goals for innovation and could be magnets for research and development. Landscape and open-space planning is tied to mobility; "smart" city planning reduces the need to travel and creates space for active transportation such as bicycling and walking. Throughout Canada, cities are increasing urban density, mixed land uses, and nonautomobile transportation options, while encouraging climate-friendly buildings and reduced energy consumption. Energy, transport, and building infrastructure last several decades and lock 
development along specific pathways (Lecocq and Shalizi 2014). Government investment should bear in mind that infrastructures built today must foster and sustain the transition to a low-carbon future (Nilsson and Eckerberg 2007). The Government of Canada's Green Infrastructure Fund could therefore play a key role in the Canadian transition (Infrastructure Canada 2015). By 2035, nearly three quarters of Canada's buildings will be new or renovated, offering the opportunity to promote a less carbon-intensive built environment.

\section{Civil society responses}

Low-carbon transportation involving more diverse modes and increased transit options (Benhaddadi et al. 2015; Payne and Stanford 2015; Sanchez Valero 2015) may provide numerous benefits. These could include expansion of the car-sharing economy (Boston 2015), job opportunities vis-à-vis creation of public transportation infrastructure (Bouchard-Boulianne 2015; Payne and Stanford 2015), enhancement of quality of life through reduced noise pollution, commuting time and road accidents (Lee 2015), and improving public health (Boston 2015; Lee 2015; Suleman 2015). According to Benhaddadi et al. (2015), city design supported by principles of functional and social density and diversity must include access points to efficient public transit networks. Similarly, Torrie (2015) envisions mixed-use, high-density cities reducing emissions, fuelled by reduced car dependence and changes in mobility needs. Boston's (2015) ideal future Canadian cities have a mixed-use neighbourhood model where, just like costs of transportation, costs of pollution are internalized. Additionally, for Lee (2015), "complete communities" should reflect social equity across ages, incomes, and abilities, by offering affordable housing, accessible residential homes, and care units.

\section{Implementation}

Scholars recognized the need for novel institutional frameworks and financing options that would enable municipalities to play a crucial role in choosing and implementing climate actions related to energy consumption. Land value tax financing alone is insufficient, because it can facilitate developer-led urban sprawl. New financing approaches such as divesting from planned road and highway expenses could be considered. Valuation of natural and constructed landscapes for ecosystem functioning and environmental management benefits (e.g., climate change mitigation via thermal cooling; Hough 2004), would be an important paradigm shift in municipal and provincial planning.

For Small and Havens (2015), electric public transit systems should be a primary focus of action. Diversification and increased availability of urban and interurban transit will help reduce the "single-occupant car" paradigm (Sanchez Valero 2015), whereas regulations could also play a key role in increasing passenger and freight vehicle efficiency (Bruce and Kadowaki 2015). Biofuels are proposed as a potential contribution to low-carbon transportation (Bruce and Kadowaki 2015; Sanchez Valero 2015; Torrie 2015). Benhaddadi et al. (2015) suggested engaging the forestry sector in the low-carbon transition via carbon stock management and biofuel production to help sustain local economies.

Cities could facilitate the adoption of renewable energy through district energy, producing and distributing renewable energy for heating and hot water (Boston 2015; Lee 2015; Small and Havens 2015). Existing buildings could harness local renewable energy such as geothermal power (Small and Havens 2015); however new building codes and efficiency standards are also needed (Benhaddadi et al. 2015; Small and Havens 2015). Building form has an impact on energy efficiency: multiplexes, row houses, and townhouses are more efficient than standalone houses, whereas woodframe low-rises can be 25\% less expensive to build than concrete buildings (Benhaddadi et al. 2015; Teasell, cited in Boston 2015). 


\section{Concerns}

Béland and Ross (2015) observed that Indigenous communities have a distinct reality; federal funding should aim to collaboratively improve quality of life on and off reserves as well as develop culturally and environmentally appropriate buildings. Donahue-Harden (2015) supported retrofitting programs' incorporation of mechanisms to reduce social inequity. Manitoba's pay-as-you-save program, through which Manitoba Hydro pays upfront energy upgrade costs and households pay from utility bill savings, was cited as an inspiring example (Table 2). Boston (2015) called for win-win situations like establishing secondary suites or separate units in low-occupancy homes for additional income during retirement.

\section{A new climate narrative: learning from the past}

The first lesson-emphasized by the scholars as well as by several contributors from civil society-is that many past extraction projects did not engage in meaningful consultation and led to little or no benefit sharing with Indigenous peoples (Béland and Ross 2015). Low-carbon pathways must include full nation-to-nation partnerships with Canadian Indigenous peoples, who from the onset should play a key role as full partners in the transition's dialogue and implementation (Béland and Ross 2015; Donahue-Harden 2015; Payne and Stanford 2015). Given Indigenous Title, Indigenous and Treaty Rights of First Nations, Inuit Land Claims, and the special circumstances of Métis and Non-Status Indians, the distinct jurisdictions of Indigenous peoples must be acknowledged in practice (Béland and Ross 2015). It is essential to recognize Indigenous peoples' abilities and rights to manage resources and lands and the role of traditional ecological knowledge for more sustainable community development.

A second lesson, highlighted by Payne and Stanford (2015), concerns the pace at which natural resources, especially, but not only, oil, are extracted. Shifting away from our "boom and bust" mentality (e.g., bulk export of raw bitumen) would facilitate the creation of more sustainable development pathways. This would ensure long-term jobs by increasing Canada's value-added contributions to natural resources both downstream and upstream of the point of extraction. In fact, Canadian energy productivity is one of the lowest of the Organization for Economic Cooperation and Development (OECD) countries (OECD 2016). Torrie (2015) suggested that energy productivity could improve if the service economy and manufacturing expanded at the expense of primary processing.

Torrie (2015) offered a third lesson when he proposed reframing the low-carbon transition challenge to facilitate the emergence of socially attractive solutions. Adoption of green buildings, he argued, is facilitated by their aesthetic, technical, and marketable value, whereas improvements in energy use are often considered secondary co-benefits. "Personal transportation" could likewise be reframed as "access", including all decisions and behaviours that reduce demand for personal mobility such as telecommuting, working from home, and teleshopping.

It has been proposed that in a democracy collaboration between responsible enterprises and engaged civil society is necessary to address global issues such as climate change (Mintzberg 2015). This paper demonstrates the existence of a range of Canadian solutions from diverse sectors of society (Table S2) and a wealth of existing inspiring initiatives (Table 2). Together with renewed leadership at the federal level (Ayed 2015) and the willingness of provincial governments and Indigenous leaders to engage in dialogue, this suggests that Canada is currently well-positioned to improve its climate action record. Noting the inability of a doom-and-gloom narrative of climate change to evoke concerted action, SCD reframed the issue to one of opportunities and solutions, garnering lavish praise from the media (see e.g., "Un plan Marshall pour le Canada"; Asselin 2015). We hope the iterative process of creating a climate narrative, including the search for consensus, broad engagement, and solutionoriented discourse, could be used to inform discussion on climate change in Canada as the country follows its COP21 commitments. 


\section{Acknowledgements}

The Sustainable Canada Dialogues initiative was developed by the UNESCO-McGill Chair Dialogues on Sustainability and made possible thanks to support from the Trottier Institute for Science and Public Policy, the Faculty of Science of McGill University, and C.P.'s Tier 1 Canada Research Chair Climate Change Mitigation and Tropical Forests. We would like to thank the contributors to Acting on Climate Change: Extending the Dialogue Among Canadians for their feedback on the draft of this paper. We would like to especially thank Alana Westwood, Ralph Torrie, Liette Vasseur, and Lana Payne for helping sharpen the paper's focus.

\section{Author contributions}

Conceived and designed the study: C Potvin. Contributed resources: C Potvin. Drafted or revised the manuscript: C Potvin, D Sharma, I Creed, S Aitken, F Anctil, E Bennett, F Berkes, S Bernstein, N Bleau, A Bourque, B Brown, S Burch, J Byrne, A Cunsolo, A Dale, D de Lange, B Dyck, M Entz, J Etcheverry, R Faucher, A Fenech, L Fraser, I Henriques, A Heyland, M Holden, G Hoberg, M Hoffmann, G Huang, A Jacob, S Jodoin, A Kemper, M Lucotte, R Maranger, L Margolis, I Mauro, J McDonnell, J Meadowcroft, C Messier, M Mkandawire, C Morency, N Mousseau, K Oakes, S Otto, P Palmater, TS Palmer, D Paquin, A Perl, A Potvin, H Ramos, C Raudsepp-Hearne, N Richards, J Robinson, S Sheppard, S Simard, B Sinclair, N Slawinski, M Stoddart, M-A Villard, C. Villeneuve, T Wright.

\section{Competing interests}

The authors have declared that no competing interests exist.

\section{Data accessibility statement}

All relevant data are within the paper and in the Supplementary Material.

\section{Supplementary material}

The following Supplementary Material is available with the article through the journal website at doi:10.1139/facets-2016-0029.

Supplementary Material 1

\section{References}

Adler D. 2016. Story of cities \#37: how radical ideas turned Curitiba into Brazil's 'green capital'. The Guardian, 6 May [online]: Available from https://www.theguardian.com/cities/2016/may/06/ story-of-cities-37-mayor-jaime-lerner-curitiba-brazil-green-capital-global-icon.

Asselin P. 2015. Un plan Marshall pour le Canada. Le Soleil, 3 April [online]: Available from http://www.lapresse.ca/le-soleil/opinions/editoriaux/201504/02/01-4857963-un-plan-marshall-pourle-canada.php.

Ayed N. 2015. Canada invited to facilitate climate talks for 1st time in a decade. CBC News, 6 December [online]: Available from http://www.cbc.ca/news/world/canada-climate-change-cop21talks-facilitator-1.3353235.

Barrington-Leigh C, and Ouliaris M. 2014. The renewable energy landscape in Canada: a spatial analysis. Working Paper No. 16-246. USAEE [online]: Available from http://wellbeing.ihsp.mcgill. ca/publications/Barrington-Leigh-Ouliaris-IAEE2015.pdf. 
Béland C, and Ross M. 2015. Decolonizing the transition towards a sustainable Canada. In Acting on climate change: extending the dialogue among Canadians. Edited by D Sharma and C Potvin. Sustainable Canada Dialogues, Montreal, Quebec. pp. 11-16.

Benhaddadi M, Blanchet P, Boucher J-F, Desgroseilliers J-F, Lachapelle E, Lessard I, et al. 2015. Operationalizing the key policy orientations of acting on climate change: solutions from Canadian scholars. In Acting on climate change: extending the dialogue among Canadians. Edited by D Sharma and C Potvin. Sustainable Canada Dialogues, Montreal, Quebec. pp. 140-146.

Berthélemy N. 2015. A comprehensive look at Canada's greenhouse gas emissions: which actions for which reduction targets? In Acting on climate change: extending the dialogue among Canadians. Edited by D Sharma and C Potvin. Sustainable Canada Dialogues, Montreal, Quebec. pp. $40-47$.

Betsill M. 2001. Mitigating climate change in US cities: opportunities and obstacles. Local Environment, 6(4): 393-406. doi:10.1080/13549830120091699.

Boston A. 2015. Local low-carbon agenda for national prosperity. In Acting on climate change: extending the dialogue among Canadians. Edited by D Sharma and C Potvin. Sustainable Canada Dialogues, Montreal, Quebec. pp. 96-102.

Bouchard-Boulianne E. 2015. The role of workers in the transition to a low-carbon economy. In Acting on climate change: extending the dialogue among Canadians. Edited by $\mathrm{D}$ Sharma and C Potvin. Sustainable Canada Dialogues, Montreal, Quebec. pp. 65-68.

Bourke P, and Chaperon C. 2015. At the crossroads. In Acting on climate change: extending the dialogue among Canadians. Edited by D Sharma and C Potvin. Sustainable Canada Dialogues, Montreal, Quebec. pp. 76-83.

Bridge G, and Le Billon P. 2013. Oil. Polity Press, Cambridge, UK.

Bruce I, and Kadowaki R. 2015. Building on the best: keeping Canada's climate promise. In Acting on climate change: extending the dialogue among Canadians. Edited by D Sharma and C Potvin. Sustainable Canada Dialogues, Montreal, Quebec. pp. 48-55.

Bulkeley H, and Betsill M. 2005. Rethinking sustainable cities: multi-level governance and the 'urban' politics of climate change. Environmental Politics, 14(1): 42-63. doi:10.1080/0964401042000310178.

Burch S, Shaw A, Dale A, and Robinson J. 2014. Triggering transformative change: a development path approach to climate change response in communities. Climate Policy, 14: 467-487. doi:10.1080/14693062.2014.876342.

Bushell S, Colley T, and Workman M. 2015. A unified narrative for climate change. Nature Climate Change, 5: 971-973. doi:10.1038/nclimate2726.

Cadoret C, and Picard-Simon N. 2015. Call to action. In Acting on climate change: extending the dialogue among Canadians. Edited by D Sharma and C Potvin. Sustainable Canada Dialogues, Montreal, Quebec. pp. 204-209.

Canton M, and Lucotte M. 2015. Hydropower: energy production par excellence in Canada, but not quite green. In Acting on climate change: extending the dialogue among Canadians. Edited by D Sharma and C Potvin. Sustainable Canada Dialogues, Montreal, Quebec. pp. 117-123. 
CESAR. 2016. Background on energy systems [online]: Available from http://www.cesarnet.ca/ background-energy-systems.

Dale A. 2005. A perspective on the evolution of e-dialogue concerning interdisciplinary research on sustainable development in Canada. Ecology and Society, 10(1): 37. doi:10.5751/ES-01373-100137.

Day A, and Fleming S. 2015. Distributed generation micro-grid systems: advancing renewable energy adoption and the evolution of our electrical grid. In Acting on climate change: extending the dialogue among Canadians. Edited by D Sharma and C Potvin. Sustainable Canada Dialogues, Montreal, Quebec. pp. 110-116.

de Graaf M. 2015. Local climate change knowledge-solutions for adaptation and education in the Fundy Biosphere Reserve. In Acting on climate change: extending the dialogue among Canadians. Edited by D Sharma and C Potvin. Sustainable Canada Dialogues, Montreal, Quebec. pp. 84-88.

Donahue-Harden A. 2015. White paper on climate change actions in Canada. In Acting on climate change: extending the dialogue among Canadians. Edited by D Sharma and C Potvin. Sustainable Canada Dialogues, Montreal, Quebec. pp. 173-180.

Environment Canada. 2013. National inventory report 1990-2013: greenhouse gas sources and sinks in Canada-executive summary [online]: Available from http://publications.gc.ca/collections/ collection_2016/eccc/En81-4-2013-1-eng.pdf.

Ereaut G, and Segnit N. 2006. Warm words: how are we telling the climate story and can we tell it better? Institute for Public Policy Research, London, UK. 32 p.

Global Compact Network Canada Environment Committee (GCNCEC). 2015. Linking the roadmap to the UNGC environmental principles. In Acting on climate change: extending the dialogue among Canadians. Edited by Sharma D, and Potvin C. Sustainable Canada Dialogues, Montreal, Quebec. pp. 19-26.

Gupta S, Harnisch J, Barua DC, Chingambo L, Frankel P, Garrido Vázquez RJ, et al. 2014. Cross-cutting investment and finance issues. In Climate Change 2014: mitigation of climate change. Contribution of Working Group III to the Fifth Assessment Report of the Inter-governmental Panel on Climate Change. Edited by O Edenhofer, R Pichs-Madruga, Y Sokona, E Farahani, S Kadner, K Seyboth, et al. Cambridge University Press, Cambridge, UK and New York, New York.

Harvey LDD. 2013. The potential of wind energy to largely displace existing Canadian fossil fuel and nuclear electricity generation. Energy, 50: 93-102. doi:10.1016/j.energy.2012.12.008.

Hough M. 2004. Cities and natural process: a basis for sustainability. Routledge, New York, New York. 304 p.

Infrastructure Canada. 2015. Green infrastructure fund [online]: Available from http://www. infrastructure.gc.ca/prog/gif-fiv-eng.html.

Jones S. 2014. Flirting with climate change: a comparative policy analysis of subnational governments in Canada and Australia. Journal of Comparative Policy Analysis: Research and Practice, 16(5): 424-440. doi:10.1080/13876988.2014.942570.

Kershaw P. 2015. Building political will for a low-carbon, high prosperity Canada project. In Acting on climate change: extending the dialogue among Canadians. Edited by D Sharma and C Potvin. Sustainable Canada Dialogues, Montreal, Quebec. pp. 189-194. 
Layzell DB. 2014. Dividing the big picture: visualizing provincial diversity. CESAR, blog post, 5 May [online]: Available from http://www.cesarnet.ca/blog/dividing-big-picture-visualizingprovincial-diversity.

Lecocq F, and Shalizi Z. 2014. The economics of targeted mitigation in infrastructure. Climate Policy, 14(2): 187-208. doi:10.1080/14693062.2014.861657.

Lee M. 2015. Envisioning a good green life in British Columbia: lessons from the climate justice project. In Acting on climate change: extending the dialogue among Canadians. Edited by D Sharma and C Potvin. Sustainable Canada Dialogues, Montreal, Quebec. pp. 181-187.

Meadowcroft J. 2011. Engaging with the politics of sustainability transitions. Environmental Innovation and Societal Transitions, 1(1): 70-75. doi:10.1016/j.eist.2011.02.003.

Meloche F. 2015. Investing to facilitate transition to a low-carbon society. In Acting on climate change: extending the dialogue among Canadians. Edited by D Sharma and C Potvin. Sustainable Canada Dialogues, Montreal, Quebec. pp. 27-31.

Miller D, Evans S, and Sharifi F. 2015. Transitioning to a renewable energy economy that respects nature and supports community well-being. In Acting on climate change: extending the dialogue among Canadians. Edited by D Sharma and C Potvin. Sustainable Canada Dialogues, Montreal, Quebec. pp. 124-129.

Mintzberg H. 2015. Rebalancing society. Berrett-Koehler Publisher, Inc., Oakland, California.

Moser SC, and Dilling L. 2007. Creating a climate for change: communicating climate change and facilitating social change. Cambridge University Press, Cambridge, UK.

New M, Liverman D, Schroeder H, and Anderson K. 2011. Four degrees and beyond: the potential for a global temperature increase of four degrees and its implications. Philosophical Transactions of the Royal Society A, 369: 6-19. PMID:21115510. doi:10.1098/rsta.2010.0303.

Nilsson M, and Eckerberg K. 2007. Environmental policy integration in practice: shaping institutions for learning. Earthscan, London, UK.

OECD. 2016. Green growth indicators [online]: Available from http://www.oecd.org/greengrowth/ greengrowthindicators.htm.

Office of Energy Efficiency. 2010. Energy efficiency trends in Canada, 1990 to 2007. Natural Resources Canada [online]: Available from http://oee.nrcan.gc.ca/publications/statistics/trends/ 2009/chapter3.cfm.

Payne L, and Stanford J. 2015. Protect the environment by doing more work, not less. In Acting on climate change: extending the dialogue among Canadians. Edited by D Sharma and C Potvin. Sustainable Canada Dialogues, Montreal, Quebec. pp. 69-74.

Peltier WR, Stone J, Takaro T, and Westwood A. 2015. On the role of Canada's scientists in transitioning to a low-carbon future. In Acting on climate change: extending the dialogue among Canadians. Edited by D Sharma and C Potvin. Sustainable Canada Dialogues, Montreal, Quebec. pp. 147-153.

Potvin C, Aitken S, Anctil F, Bennett E, Berkes F, Byrne J, et al. 2015. Acting on climate change: solutions from Canadian scholars. Sustainable Canada Dialogues, Montreal, Quebec. 
Province of British Columbia. 2008. Climate Action Plan, British Columbia [online]: Available from http://www.gov.bc.ca/premier/attachments/climate_action_plan.pdf.

Raphals P, and Hendriks R. 2015. Towards a sustainable low-carbon electric system: challenges and opportunities. In Acting on climate change: extending the dialogue among Canadians. Edited by D Sharma and C Potvin. Sustainable Canada Dialogues, Montreal, Quebec. pp. 130-138.

Richard G, and Perl A. 2010. Transport revolutions: moving people and freight without oil. New Society Publishers, Gabriola Island, British Columbia.

Richards N, Stoddart M, Cunsolo-Willox A, Potvin C, Berkes F, Bleau N, et al. 2015. Imagining Canada: an exploration of desired futures from a countrywide visioning approach. In Acting on climate change: extending the dialogue among Canadians. Edited by D Sharma and C Potvin. Sustainable Canada Dialogues, Montreal, Quebec. pp. 155-163.

Risbey JS. 2008. The new climate discourse: alarmist or alarming? Global Environmental Change, 18: 26-37. doi:10.1016/j.gloenvcha.2007.06.003.

Robitaille J. 2015. The role of education in the transition to a low-carbon economy. In Acting on climate change: extending the dialogue among Canadians. Edited by D Sharma and C Potvin. Sustainable Canada Dialogues, Montreal, Quebec. pp. 195-199.

Sanchez Valero C. 2015. Building on expertise and innovation by supporting businesses and municipalities. In Acting on climate change: extending the dialogue among Canadians. Edited by D Sharma and C Potvin. Sustainable Canada Dialogues, Montreal, Quebec. pp. 89-94.

Sharma D, and Potvin C, eds. 2015. Acting on climate change: extending the dialogue among Canadians. Sustainable Canada Dialogues, Montreal, Quebec.

Small M, and Havens C. 2015. Transitioning cities to 100\% renewable energy. In Acting on climate change: extending the dialogue among Canadians. Edited by D Sharma and C Potvin. Sustainable Canada Dialogues, Montreal, Quebec. pp. 103-108.

Suleman S. 2015. Perspective from youth and health. In Acting on climate change: extending the dialogue among Canadians. Edited by D Sharma and C Potvin. Sustainable Canada Dialogues, Montreal, Quebec. pp. 200-203.

Torrie R. 2015. Some reflections on climate change response policy. In Acting on climate change: extending the dialogue among Canadians. Edited by D Sharma and C Potvin. Sustainable Canada Dialogues, Montreal, Quebec. pp. 56-63.

Vasseur L, and Pickering G. 2015. Feeding the social animal: how to engage Canadians in climate change mitigation. In Acting on climate change: extending the dialogue among Canadians. Edited by D Sharma and C Potvin. Sustainable Canada Dialogues, Montreal, Quebec. pp. 166-171.

Vaughan S. 2015. Climate investment, low-carbon innovation and green industrial policy. In Acting on climate change: extending the dialogue among Canadians. Edited by D Sharma and C Potvin. Sustainable Canada Dialogues, Montreal, Quebec. pp. 32-38.

Wilbanks TJ, and Sathaye J. 2007. Integrating mitigation and adaptation as responses to climate change. Mitigation and Adaptation Strategies for Global Change, 12: 957-962. doi:10.1007/ s11027-007-9108-3. 